\title{
Aporia Phila z perspektywy teorii aktów mowy
}

\author{
Bartosz Biskup \\ Uniwersytet Jagielloński w Krakowie \\ bartosz.biskup@me.com
}

Otrzymano 7 grudnia 2017, zaakceptowano 21 stycznia 2018, opublikowano 26 kwietnia 2018.

\begin{abstract}
Abstrakt
Celem niniejszego artykułu jest przedstawienie tak zwanej Aporii Phila (possibility puzzle) przedstawionej przez Shapiro (2011) w kontekście sporu konwencjonalizm-nonkonwencjonalizm w teorii aktów mowy. Konwencjonalizm utrzymuje, że dla każdego aktu mowy istnieje konwencja, która determinuje moc illokucyjną aktu. Wykonać w pełni fortunny akt mowy to spełnić wystarczające i konieczne warunki określone dla danego aktu mowy. Nonkonwencjonalizm krytykuje pogląd, że dla każdego aktu mowy istnieje określona konwencja oraz ukryte warunki, które należy spełnić. Ten pogląd utrzymuje konwencjonalną tezę dla tak zwanych stricte konwencjonalnych aktów mowy (na przykład performatywów), ale neguje użycie dużego kwantyfikatora dla tak zwanych komunikacyjnych aktów mowy, których celem jest, w skrócie, wyrażenie pewnej intencji i zmuszenie kogoś poprzez jej wyrażenie do określonego postępowania. Phil, bohater historii z książki Shapiro (2011), podkreślił, iż zawsze musi istnieć reguła upoważniająca do tworzenia prawa. Ten zarzut dotyczący „Pierwszego Legislatora” jest zasadny tylko z perspektywy konwencjonalizmu. Jeżeli można utrzymywać, że akt mowy Pierwszego Legislatora może być nonkonwencjonalny, wtedy argument Phila jest nietrafny. Na końcu scharakteryzowany jest następujący fenomen: tylko prawnicy analizują ,pierwsze akty mowy”, natomiast dla filozofów problem ,pierwszego pytania” nie jest tak absorbujący.
\end{abstract}

Słowa kluczowe: konwencjonalizm; nonkonwencjonalizm; Aporia Phila; teoria aktów mowy; Shapiro. 
Celem niniejszego artykułu ${ }^{1}$ jest zbadanie sposobu, w jaki teoria aktów mowy, rozwijana w ramach pragmatyki w filozofii języka oraz lingwistyce, może przysłużyć się analizie jednego z głównych problemów współczesnego pozytywizmu prawniczego - uzasadnienia pierwszych norm prawnych.

Wpływ, jaki pragmatyka wywiera na teorię prawa, nie jest często podkreślany, pomimo istnienia silnych związków pomiędzy niektórymi koncepcjami teoretycznoprawnymi a ujęciami wywodzącymi się z pragmatyki w filozofii języka. Teoria aktów mowy to jednocześnie bardzo pomocne narzędzie przy rozpatrywaniu pewnych szczegółowych zagadnień prawoznawstwa, na przykład teorii czynności prawnych czy orzeczeń sądowych (zob. Liu, Liu, 2007).

W niniejszej pracy zarysuję ogólną teorię aktów mowy zaproponowaną przez Johna Searle'a, która stanowi rozwinięcie teorii J. L. Austina. Następnie przejdę do omówienia dyskutowanych w pozytywizmie prawnym oraz teorii aktów mowy genetycznych tez dotyczących odpowiednio prawa i aktów mowy. Zaproponuję ujmowanie fenomenu prawa w ramach pojęć i koncepcji, które rozwinęły się w dyskusji o genezie aktów mowy. Odwołam się przy tym do opisanej przez Shapiro (2011) tak zwanej Aporii Phila (possibility puzzle). W ostatniej części przedstawię propozycję traktowania Aporii Phila jako zagadki trywialnej, która z perspektywy filozoficznej nie jest aż tak interesująca, jak się na początku wydaje.

\section{Aporia Phila}

Shapiro (2011), opierając się na Hartowskich przykładach (Hart, 1998), przedstawił hipotetyczny model powstania prawa, który miał jak w soczewce skupiać problemy związane z uzasadnieniem pierwszych reguł prawnych:

Wyobraźmy sobie, że prawo zostało wymyślone 1 stycznia, 10000 lat przed naszą erą w małej wiosce na Żyznym Półksiężycu, której mieszkańcy trudzą się rolnictwem. W tym dniu wiejski starzec Lex miał pewien pomysł, więc zwołał naradę społeczności, aby go ogłosić. Powiedział zebranym: „Wielu z was przybywało ostatnio do mnie, aby donosić mi o wzrastającym rozłamie w społeczności wiejskiej. Obecnie spędzamy sporo wolnego czasu na naradach, słuchając skargi za skargą, dyskutując wagę każdej z nich, bez końca deliberując nad tym, jak bardzo każda rodzina musi pomagać innej w czasie upraw i zbiorów... [wskazuje na inne problemy dnia codziennego - B.B.]. Rok po roku, gdy nasza wioska rośnie, sytuacja staje się coraz gorsza. Przypomnijcie sobie, jak nie byliśmy w stanie rozwiązać sprawy dziesięciny ostatniego roku i w rezultacie skończyło nam się zboże przed zbiorami. [...] Aby rozwiązać tę sytuację proponuję następujący sposób postępowania: [1] Przedstawię zbiór reguł, które dotyczyć będą naglących obecnie spraw. Będziecie wiedzieć, kiedy stworzyłem regułę, gdy [2] wydam rozkaz, [3] siedząc pod wielką palmą na wiejskim rynku. Mój osąd będzie ostateczny i nikt nie będzie mógł się mi sprzeciwiać. Wreszcie, kiedy umrę,

\footnotetext{
${ }^{1}$ Bardzo dziękuję za wszystkie uwagi i komentarze, które do wcześniejszej wersji tekstu przedstawił mi Pan Prof. Tomasz Gizbert-Studnicki. Chciałbym też w tym miejscu podziękować za niezwykle cenne opinie dwóm anonimowym recenzentom.
} 
wszystkie reguły pozostaną w mocy, a jedno z moich dzieci przejmie stanowisko zarządcy wsi. Mój wybrany sukcesor oczywiście może zmienić reguły, jeżeli tego zechce". (Shapiro, 2011, s. 37; numeracja, tłumaczenie i wyróżnienie moje - B.B.)

Hipotetyczna sytuacja odnosi się więc do momentu, w którym po raz pierwszy dochodzi do ustanowienia prawa. Tylko jeden mieszkaniec Żyznego Półksiężyca, Phil, nie zgodził się z propozycją Lexa. Mimo zauważenia szczytnych intencji, jakie przyświecają Lexowi, mówi mu:

Widzisz, abyś miał moc tworzenia, zmiany i stosowania reguł dla naszej wioski, musi istnieć jakaś reguła dająca Ci upoważnienie do tego. Ale żadna taka reguła nie istnieje. Jeżeli próbujesz stworzyć jakąś regułę pod palmą bez reguły dającej Ci do tego upoważnienie, to jest ona takiej samej mocy, jak gdybym ja próbował ją stworzyć, czyli ,żadnej”. (Shapiro, 2011, s. 38; thumaczenie moje)

Żywot Sokratesa dobitnie pokazuje, jak bardzo niewygodni dla porządku społecznego są filozofowie. Z Philem można postąpić więc albo tak, jak zrobiono to z Sokratesem, albo wykazując istnienie wymaganej przez niego reguły, albo wskazując na to, iż Phil po prostu się myli.

W niniejszym artykule będę bronił tej ostatniej z wymienionych strategii. Wykażę, iż rodowód prawa jest podobny do rodowodu aktów mowy, a przez to debata nad aktami mowy mutatis mutandis jest też debatą nad samym prawem - wskazując jednak na pewne ograniczenia tej analogii. Ludzie z tych samych względów posługują się aktami mowy co regułami, nakazami i, w szczególności, prawem. Wreszcie, prawo przez swoją funkcję regulowania kontaktów społecznych stało się najbardziej rozwiniętym z aktów mowy.

\subsection{Zasady Jajka i Kury}

Aporię Phila można rozważać jako problem typu ,jajko czy kura?”, co uwydatnia dwie składające się na niego części (Shapiro, 2011, s. 40).

Zasada Jajka: Ktoś może ustanowić normę prawną tylko wtedy, gdy istniejąca norma przyznaje mu taką moc.

Zasada Kury: Norma przyznająca moc do ustanawiania norm prawnych istnieje tylko wtedy, gdy ktoś mający odpowiednią moc ją ustanowił.

Po takim przeformułowaniu pozostaje już tylko zadać pytanie: co było wcześniej, kura czy jajko? Po pierwsze, można Aporię Phila traktować jako problem logiczny. Określenie rzeczywistej relacji pomiędzy dwiema zasadami pozwoli w takim wypadku na przezwyciężenie problemu. Po drugie, na co wskazuje Poggi (2013), problem ten w takiej formule jest wieloznaczny. ,Jak mówi powiedzenie, kiedy spotykasz jakiś paradoks, sprawdź, czy nie kryje się za nim wieloznaczność” (Poggi, 2013, s. 32; tłumaczenie moje). Poggi zauważa, że terminy „norma prawna”, ,istniejąca norma” oraz „moc do ustanawiania norm” posiadają po co najmniej dwa znaczenia. Aporia, po wskazaniu wieloznaczności terminów, ulega według Poggi tylko częściowemu rozwiązaniu, gdyż nadal pozostaje do rozwiązania fundamentalny problem, jak autor podstawowych norm ma moc ich wprowadzania do 
systemu prawnego bez bycia do tego wcześniej autoryzowanym przez inne normy należące do danego systemu (obowiązujące w nim)?” (Poggi, 2013, s. 35; thumaczenie moje). Wydaje się jednak, że jest to parafraza samej aporii, w wyniku której żaden z jej elementów nie uległ rozwiązaniu.

Ze względu na sposób wyjaśniania genezy takiego zjawiska jak prawo współcześnie najmniej interesujące są stanowiska prawnonaturalne. Uzasadniają one prawo za pomocą znanej od starożytności metody radzenia sobie z regresem w nieskończoność: pierwszej przyczyny. Stanowiska prawnonaturalne zakładają więc obowiązywanie prawa w Bogu lub innym pojedynczym przedrozumowym bycie, nie wyłączając $z$ tego natury człowieka. Stanowiska te są mało interesujące, gdyż wypracowana w naukach ścisłych kontestacja luki eksplanacyjnej (explanatory gap) została zaakceptowana również przez nauki humanistyczne i społeczne. Rozwiązanie orędowników prawa naturalnego przypomina sytuację z rysunku Sidneya Harrisa, na którym matematyk rozwiązywał na tablicy trudne zagadnienie matematyczne, jednak w kroku drugim umieścił zdanie ,a wtedy stał się cud”2. Pozytywiści-prawnicy chcą być jak drugi uczony, który na dowód matematyczny tego pierwszego reaguje: „Myślę, że powinieneś być bardziej precyzyjny w kroku drugim”. Podważenie tej argumentacji to jedno, przedstawienie satysfakcjonującej i nieobarczonej błędem regresu ani luką eksplanacyjną teorii to coś innego.

\subsection{Rozwiązanie pozytywizmu}

Shapiro (2011) przedstawia historyczne rozwiązania Aporii Phila. J. Austin (prawnik ${ }^{3}$ ) rozwiązał problem poprzez odrzucenie zasady jajka, natomiast Hart poprzez odrzucenie zasady kury. Motywacją J. Austina była rozwijana przez niego koncepcja, dająca się streścić do tezy: prawem jest poparty sankcją rozkaz suwerena. Natomiast suwerenem był ten, którego rozkazy stanowią dla innych rację do działania i który sam nie był podporządkowany żadnej wyższej władzy. Jak wskazuje Poggi (2013, s. 26), J. Austin swoją koncepcję opiera na przezwyciężeniu problemu relacji pomiędzy zdaniami deskryptywnymi a zdaniami normatywnymi (znany jako gilotyna Hume'a, ang. is-ought problem, zob. Osmola, Załuski, 2017). Wszystkie zdania w teorii Austina mają być deskryptywne, w związku z tym powyższy problem ma nie dotyczyć jego teorii (Shapiro, 2011, s. 57-58). Jak wskazuje jednak Shapiro, jego posunięcie polega na redefinicji zdań i pojęć prawnych z normatywnych na deskryptywne i poprzez taki zabieg ominięcie rdzenia problemu. Jednak w rzeczywistości, gdy mówimy, iż ktoś jest zobowiązany do czegoś, winny, bądź popełnił wykroczenie, to używamy tych pojęć, by wskazać na pewne racje do działania lub na to, że ktoś powinien był zachować się inaczej. Jak pisze Shapiro, zapożyczając sformułowanie od Sellarsa, są one „najeżone powinnością” (ang. fraught with ought; Shapiro, 2011, s. 77-78).

\footnotetext{
${ }^{2}$ Sidney Harris, Then a miracle occurs... Dostęp 10 listopada 2017 z: http://www.sciencecartoonsplus.com/gallery/math/math07.gif

${ }^{3}$ Pisząc „J. Austin” będę odnosił się do Johna Austina, brytyjskiego prawnika. Pisząc „J. L. Austin”, albo po prostu „Austin”, będę odnosił się do Johna Langshaw Austina, brytyjskiego filozofa analitycznego.
} 
Krytyka koncepcji J. Austina dokonana przez Harta opiera się między innymi na wskazaniu, iż nie rozróżniał on punktu widzenia zew nętrzne go (opis pewnych nawyków przez zewnętrznego obserwatora) od we w n ę tr z n e go (członka danej społeczności). Rozróżnienie normy prawnej od zwyczajów i nawyków gwarantuje jedynie przyjęcie tego drugiego punktu widzenia. Normy według Harta mogą powstawać również w sposób niepochodzący od jakiegoś suwerena - odrzuca on więc zasadę kury. Może zdarzyć się, że normy są efektywne, ustanowione w odpowiedniej procedurze, ale jednocześnie żadna osoba może nie dawać im posłuchu. Hart podkreśla więc, że reguły społeczne mogą być zredukowane do społecznych praktyk, będąc niejako ich wyrazem. Taki charakter ma właśnie reguła uznania, która

nie jest sama obowiązującą regułą, lecz stanowi standard oceny obowiązywania wszystkich pozostałych reguł lub norm prawnych. Zatem reguła uznania istnieje i jest wiążąca, lecz nie jako obowiązująca reguła systemu prawa, ale jako reguła społeczna, która jest akceptowana i praktykowana przez stosujących prawo urzędników systemu (stanowi standard publiczny, common public standard). (Dyrda, 2013, s. 27; wyróżnienie oryginalne)

W pewien sposób reguła uznania jest więc kolista. Relację pomiędzy praktyką a normą można określić jako wzajemne sprzężenie.

Rozwiązaniem Shapiro (2011), któremu poświęcona jest cała Legality, jest planowa teoria prawa. Według niego dany podmiot posiada moc prawną (czyli kompetencję z zasady jajka) w danym systemie prawnym, gdy: ,(1) systemowy główny plan upoważnia dany organ do planowania dla innych oraz (2) członkowie danej społeczności traktują go jako upoważnionego do tego" (Shapiro, 2011, s. 180; tłumaczenie moje). Plan ten jest racjonalny, Shapiro poszukuje więc wsparcia normatywności w racjonalności instrumentalnej. Z jednej strony, takie stanowisko można uważać za niepozytywistyczne (Chiassoni, 2013), odwołujące się do pewnych normatywnych zjawisk, uniwersalnych i niezależnych od faktów społecznych norm racjonalności (Gizbert-Studnicki, 2016). Z drugiej strony, jak wskazuje Poggi (2013), krytyka planu z perspektywy racjonalności nie jest jeszcze krytyką prawną, mówiącą, iż ktoś nie ma mocy zezwalającej na normowanie. Złamanie zasad racjonalności nie musi implikować złamania zasad prawnych.

W niniejszym artykule samej Aporii Phila nie będę jednak traktować jako zagadki logicznej, rozumianej w wyżej przedstawiony sposób. Lex w przytoczonej wcześniej historii dokonał pewnego aktu mowy. Jeżeli potraktować prawo jako twór konstytuowany przez akty mowy, to otwiera się nowe pole eksplanacyjne, które może pozwolić na badanie genezy prawa. Zasadnicze pytanie, jakie należy postawić, to pytanie, czy akt mowy Lexa był udany. Mam tu na myśli ,udaność” w sensie illokucyjnym, to jest pytanie, czy akt ten wywołał skutek illokucyjny w postaci stworzenia obowiązującej reguły. Nie będę się zajmował skutkiem perlokucyjnym, który w omawianym przypadku polegałby na dawaniu przez mieszkańców Żyznego Półksiężyca posłuchu regule ustanowionej przez Lexa. Nie jest więc też interesująca $z$ tej perspektywy sama relacja pomiędzy traktowaniem przez społeczność Lexa jako 
osoby wiedzącej, co najlepiej robić (autorytet epistemiczny), a traktowaniem go jako osoby, której zdanie liczy się jako wzorzec postępowania (autorytet deontyczny) ${ }^{4}$.

\section{Ogólna teoria aktów mowy}

Pierwsze pytanie, jakie warto zadać to: czym właściwie jest akt mowy? Aktami mowy są te akty, które możemy (ale nie musimy) wykonywać poprzez mówienie, że coś robimy (Green, 2007). Aktem mowy jest więc powiedzenie: „odrzucam twoją propozycję”, gdyż przez wygłoszenie tej wypowiedzi propozycja zostaje odrzucona. Aktem mowy w tym rozumieniu nie jest natomiast obrażenie kogoś, gdyż nie obrażę nikogo, mówiąc: „obrażam cię". Są więc nimi między innymi: stwierdzanie, przepraszanie, pytanie czy rozkazywanie. Na gruncie teorii aktów mowy akt mowy ma trzy komponenty: akt lokucyjny (akt wygłoszenia wypowiedzi o pewnej budowie składniowej i pewnym znaczeniu semantycznym), akt illokucyjny oraz, niekiedy, akt perlokucyjny (to jest akt wywołania pewnych faktycznych skutków u odbiorców wypowiedzi, na przykład wywołania obawy lub rozbawienia). Warto podkreślić, iż często wypowiedzi zawierają ukryty czasownik wskazujący na dokonywaną czynność. Zdanie będące asercją „Pada deszcz” można zamienić na wypowiedź zawierającą czasownik „Stwierdzam, że...” - forma taka jest jednak w większości przypadków redundantna.

\subsection{Pojęcie mocy illokucyjnej}

Każdy akt mowy posiada według Austina (1993, s. 645) aspekt illokucyjny, czyli funkcję realizowania określonej mocy illokucyjnej (na przykład moc stwierdzenia, moc obietnicy). Zrealizowanie mocy illokucyjnej wypowiedzi prowadzi do powstania skutku illokucyjnego. I tak, na przykład, gdy mówię „ostrzegam cię, że ten pies gryzie”, to wykonuję illokucyjny akt ostrzeżenia i wywołuję skutek polegający na ostrzeżeniu. Gdy mówię „przyrzekam, że uczynię p”, to dokonuję aktu złożenia obietnicy i wywołuję skutek polegający na powstaniu mojego zobowiązania do uczynienia p. Formuła odróżniająca illokucje od innych aspektów aktów mowy to: „Powiedzenie X było uczynieniem Y”, dla X-a będącego wypowiedzią oraz Y-ka wskazującego na tak zwany skutek illokucyjny. Poniżej, mówiąc „akt mowy”, będę miał na myśli właśnie tak rozumiany akt illokucyjny.

W tym zakresie język, w opinii Austina i Searle’a, jest strukturą normatywną, gdyż do realizacji tych czynności dochodzi jedynie poprzez w y w o ł a n i e zrozu mi e n i a (securing uptake). Wywołanie zrozumienia polega na trafnym określeniu mocy illokucyjnej wypowiedzi (na przykład na określeniu, że wypowiedź jest pytaniem, stwierdzeniem czy ostrzeżeniem).

\footnotetext{
${ }^{4} \mathrm{~W}$ zarysie pojęcia te, i wzajemne relacje pomiędzy nimi, wprowadzam w części 3.4.1, gdy zastanawiam się nad warunkami fortunnego aktu mowy.
} 
W teorii aktów mowy analogonem dla wartości logicznej jest pojęcie fortunności. Fortunne są te wypowiedzi, które spełniły określone warunki dla danej illokucji. W pełni poprawnie (pod każdym możliwym względem) dokonany akt mowy nazywa się fo r t u n n y m aktem mowy. Jeżeli ktoś powie: ,przyrzekam ci, że uczynię p, ale nie mam zamiaru uczynienia p", to nie powiedzie mu się złożenie obietnicy i nie dojdzie do powstania illokucyjnego skutku obietnicy.

\section{Geneza prawa a podstawy aktów mowy}

Teoria aktów mowy może posłużyć jako narzędzie do badania samego prawa i istniejących w niej instytucji z punktu widzenia specyficznej ontologii aktów mowy. Jeżeli prawo można analizować w kategoriach teorii aktów mowy, to mutatis mutandis można aplikować rozważania dotyczące ontologii i genezy aktów mowy do prawa.

\subsection{Hipoteza genetyczna - pytanie o fundament prawa}

Hart (1998) wskazał, że istotową cechą prawa jest to, że zawiera ono dwa rodzaje reguł. Reguły pierwotne to reguły nakładające na adresatów obowiązki i przyznające im uprawnienia (na przykład zakaz zabijania, uprawnienie do korzystania z własności). Natomiast reguły wtórne to reguły odnoszące się do tych pierwszych, a w szczególności wskazujące, jak reguły pierwotne maja być tworzone, zmieniane i stosowanie. Pośród reguł wtórnych znajduje się bardzo ważna dla teorii Harta reguła uznania (rule of recognition), która „określa jakąś cechę lub też cechy, których posiadanie przez daną regułę będzie traktowane jako konkluzywne potwierdzenie tego, że owa reguła zostanie poparta przez nacisk społeczny danej grupy" (Hart, 1998, s. 134).

Umieszczając w tym kontekście omawianą Aporię Phila, warto podkreślić, że dotyczy ona właśnie kwestii uzasadnienia dla istniejącego już fenomenu, czyli prawa. Phil zarzuca Lexowi, że prawo nie może powstać w sposób wskazany przez Lexa, gdyż brakuje reguły, która dawałaby moc Lexowi do tworzenia reguł. Jednak ustalenie, że wypowiedź Lexa była aktem mowy, który został dokonany fortunnie, pozwoli ominąć Aporię Phila - nawet bez wskazywania na regułę, która miałaby stać u podstaw aktu mowy Lexa. Spór ten dotyczy pewnego fundamentalnego zagadnienia powstającego na gruncie teorii aktów mowy - pytania o to, czy fortunność aktów mowy wyznaczona jest zawsze przez pewną uprzednio istniejącą konwencję (konwencjonalizm), czy też fortunność aktu mowy nie (zawsze) zależy od takiej konwencji (nonkonwencjonalizm).

Po przeformułowaniu problemu na język teorii aktów mowy, powstaje w związku z tym następujący dylemat: czy 1) może zaistnieć jakikolwiek akt mowy, który nie jest ugruntowany w istniejącej uprzednio konwencji, a więc jest „,pierwszym” aktem mowy danego rodzaju, a pomimo to jest fortunny i wywołuje skutek illokucyjny (chrzest pierwotny), czy też 2) każdy akt mowy musi odnosić się do wcześniej istniejącej konwencji dotyczącej 
aktów mowy danego rodzaju. Jeżeli odpowiedź 1) jest prawdziwa, to należy zadać pytanie, czy akt mowy „normowania” jest właśnie takim aktem, który nie wymaga uprzednio istniejącej konwencji.

\subsection{Konwencjonalizm w teorii aktów mowy}

\subsubsection{Anscombe o dwóch rodzajach faktów}

Anscombe (1958) odróżnia fakty surowe (ang. brute facts) od takich, które nie mogą wystąpić bez pewnego zaplecza społecznego. Pierwsze fakty (surowe) dotyczą pewnych zdarzeń fizykalnych: na przykład tego, że Jan wziął ziemniaki. Drugi rodzaj faktów, potem zwanych instytucjonalnymi, istnieją jedynie poprzez przekształcenie faktów prostych za pomocą reguł. Pytanie, jakie stawia Anscombe, jest następujące: czy fakty instytucjonalne można zredukować do faktów surowych?

Bycie dłużnym sklepikarzowi za ziemniaki opiera się na faktach surowych (złożeniu zamówienia, dostarczeniu przez niego ćwierci kilograma ziemniaków itd.) w określonym kontekście naszych instytucji (Anscombe, 1958, s. 70). W związku z tak postawionym pytaniem Anscombe stwierdza, że prawdziwe jest jedno z dwojga: albo a) zachodzi równoważność pomiędzy tymi wydarzającymi się faktami a byciem dłużnym, albo b) powiedzenie tego, że jestem dłużny, dodaje jakąś treść do zdania opisującego wydarzenie się tych faktów. Anscombe, podobnie jak później Searle, opowiada się za brakiem równoważności pomiędzy danym faktem instytucjonalnym a zbiorem konstytuujących go czynności opisywalnych w terminach fizykalnych i kauzalnych (faktami surowymi). Fakt instytucjonalny, jak argumentuje filozofka, to coś będącego ,ponad” tymi opisywanymi surowymi faktami, coś, czego nie da się zastąpić w zdaniu deskrypcją.

\subsubsection{Reguły regulatywne i konstytutywne}

Transformacja faktów surowych w fakty instytucjonalne odbywa się właśnie poprzez język (Searle, 2005) przy pomocy odpowiednich reguł.

Searle przywołuje dychotomiczny podział na dwa rodzaje reguł: regulatywne i konstytutywne ${ }^{5}$. Pierwsze z nich „regulują formy zachowań istniejących uprzednio lub niezależnie” (Searle, 1987, s. 49). Reguły regulatywne przybierają formę imperatywów. Są nastawione na pewien skutek, nakazują wykonanie jakiejś czynności, aby ten skutek osiągnąć. Czynności mogą istnieć jednak bez tych reguł, które nie tworzą same z siebie nowych stanów rzeczy. Przykładem może być następujące sformułowane: „Jeżeli chcesz upiec ciasto, to połącz wszystkie składniki i włóż je do piekarnika” albo „Samochody powinny poruszać się po prawej stronie!” Zarówno pieczenie ciasta, jak i ruch samochodów istniałyby bez tych reguł.

\footnotetext{
${ }^{5}$ Dostrzeżenie występowania omawianych reguł po raz pierwszy pojawia się u Rawlsa (1955).
} 
Regułami konstytutywnymi są natomiast takie reguły, które można sparafrazować do formy: „X w kontekście C uchodzi za Y”, gdzie Y jest stanem rzeczy konstytuowanym właśnie poprzez tę regułę. W związku z tym na przykład sporządzenie testamentu polega na spełnieniu określonych w kodeksie cywilnym zachowań i ich cech (podpisanie się, własnoręczność, określona intencja itd.), w odpowiednim kontekście, to jest kontekście istnienia kodeksu cywilnego. Konkretny zbiór zachowań polegający na napisaniu czegoś na kartce papieru i podpisaniu mógłby zaistnieć, gdyby nie było pojęcia sporządzania testamentu. Od istnienia określonych reguł zależy, czy sporządzenie testamentu może realizować się poprzez pewien zbiór faktycznych zachowań. Reguły sprawiają, że pewne faktyczne zachowania „liczą się jako” sporządzenie testamentu. Co więcej, sama osoba zachowująca się w określony sposób nie musi być świadoma tego, iż jakieś reguły spełnia, albo w ogóle może nie potrafić ich wymienić. Nie muszę, grając w szachy, znać dokładnie wszystkich reguł tej gry. Po prostu wiem, że dane zachowanie, pewne ruchy, znaczenia im przypisane, są traktowane jako gra w szachy. Co więcej, sama gra w szachy składa się z wielu zachowań, które również możliwe są jedynie na gruncie reguł konstytutywnych, na przykład mat, roszada. Podobnie sprawa ma się z językiem, za którym kryje się cały szereg ukrytych społecznych reguł i konwencji uznawania pewnych zachowań (wypowiadania dźwięków) za dokonywanie aktów mowy określonej mocy (por. Searle, 1987, s. 59-60).

Searle stoi więc, podobnie jak Austin, na stanowisku silnego konwencjonalizmu (force conventionalism; Green, 2009, s. 148). Według tego stanowiska dla każdego aktu mowy istnieje pewna konwencja, do której ten akt się odwołuje. Reguły określone przez tę konwencję decydują o fortunności aktu mowy.

Typy aktów mowy różnicowane są ze względu na ich moc illokucyjną, czyli funkcję, z jaką dana wypowiedź jest wygłoszona. Każdemu typowi aktów mowy przypisany jest pewien zbiór warunków koniecznych i wystarczających, których realizacja pozwala na skuteczne dokonanie aktu illokucyjnego o zamierzonej mocy illokucyjnej. Jedna i ta sama wypowiedź może być użyta do dokonania aktu prośby, rozkazu czy stwierdzenia. Pojęciowo możemy wyodrębnić więc akt mowy polegający na: rozkazywaniu, normowaniu czy uchwalaniu ustaw. Kolejnym krokiem analizy powinno być określenie warunków, jakie muszą zajść, aby akt mowy danego rodzaju został fortunnie dokonany.

\subsubsection{Warunki fortunności aktów mowy}

Skoro konwencjonaliści zajmują się 1) analizą zbioru koniecznych i wystarczających warunków wykonywania czynności mowy oraz 2) wydobyciem z nich reguł użycia środków językowych (Searle, 1987, s. 35), to metoda porównana może zostać do wypisywania reguł gry w szachy, w które wcześniej już nauczyliśmy się grać. ${ }^{6} \mathrm{~W}$ związku z tym możemy

\footnotetext{
${ }^{6} \mathrm{~W}$ podobny sposób, opisując prawo, postępuje Hart (1998), który odróżnia wewnętrzny i zewnętrzny pogląd na prawo. W mojej opinii, wewnętrzny i zewnętrzny punkt widzenia razem wzięte to sposób analizy zjawisk społecznych, który przedstawia Searle jako jedną, spójną metodę analizy. W przypadku jednak Searle’a metody te
} 
założyć, że będzie adekwatna wtedy, kiedy zapoznając się z regułami wykonywania pewnych aktów mowy, będziemy wiedzieć, że właśnie o tę czynność chodzi. Teoria Searle’a jest deskryptywna, ponieważ dąży do odtworzenia funkcjonujących w języku reguł dokonywania określonych aktów mowy.

Te wszystkie zagadnienia dotyczą for t un n ości aktów mowy. Fortunne są te wypowiedzi, które spełniły określone warunki dla danej illokucji.

Fortunność zdefiniuję kontekstowo, nawiązując między innymi do prac Austina (1993), Searle’a (1976, 1983) i Harnisha (2009), poprzez użycie pojęć (1) udaności i (2) defektywności. Czynność mowy jest wtedy i tylko wtedy fortunna, gdy spełnia cechę (1) oraz nie spełnia cechy (2). Akt mowy jest udany, gdy spełnia warunki fortunności dla danej illokucji, a to znaczy, że jest rozpoznany jako akt mowy o danej mocy oraz na podstawie zachowania mówiącego można stwierdzić, że są spełnione wszystkie jego warunki. Natomiast akt mowy jest obarczony defektem, gdy przynajmniej jeden z warunków nie zostaje spełniony. Owo niespełnienie warunku (warunków), powodujące obarczenie aktu mowy defektem, może nie być uświadomione przez osobę dokonująca aktu lub adresata wypowiedzi. Rozkaz wydany osobie, która nie wchodzi z mówiącym w relację bycia podwładnym $^{7}$ nie będzie udany, gdyż dla rozkazu warunkiem koniecznym jest zachodzenie relacji bycia przełożonym pomiędzy mówiącym i odbiorcą. Natomiast obietnica będzie obarczona defektem, gdy mówiący zataił fakt, że nie ma zamiaru spełnić obietnicy (gdyby go nie zataił, akt mowy byłby nieudany). W związku z tym akty mowy, które nie są udane, nie doprowadzą do zamierzonego skutku illokucyjnego. Akty illokucyjne obarczone defektem występują często w komunikacji międzyludzkiej. Są to nieszczere gratulacje, nieprzemyślane i nieszczere obietnice ${ }^{8}$.

Przejdę teraz do rozwinięcia terminu „warunków” dla danego typu czynności mowy.

\footnotetext{
nie są wyróżniane, a czasem zdania z Hartowskiego wewnętrznego punktu widzenia służą Searlowi do formułowania zdań z zewnętrznego punktu widzenia (jest on naturalistą w tym zakresie). Pojęcia takie jak ,„aut” oraz „gol” Hart (1998, s. 143) traktuje jako należące do opisu z wewnętrznego punktu widzenia, używając ich odnosimy się do reguł gry, które podzielamy wraz z innymi graczami. Można też próbować bronić tezy, że analiza Searle'a jest wręcz ograniczona do wewnętrznego punktu widzenia (zob. Searle, 1987, s. 26), gdyby porównywać analizę zjawisk innych niż prawo i język. Obydwaj autorzy często odnoszą się do różnych dyscyplin sportowych, które traktują jedynie jako zobrazowanie swoich metod, ale innemu badaczowi mogą posłużyć do porównania ich metod.

${ }^{7}$ Jest to pojęcie techniczne. Relacja bycia podwładnym dotyczy również relacji zależności (na przykład pomiędzy dzieckiem a rodzicem).

${ }^{8} \mathrm{~W}$ zależności jednak od przyjętego stanowiska w sporze internalizm-eksternalizm na gruncie teorii aktów mowy, pomimo defektu, taki akt mowy może być w pełni skuteczny, a omawiana nieszczera obietnica możliwa do wyegzekwowania - w takim wypadku nadawca odpowiada za uzasadnione przekonanie odbiorcy komunikatu, że tenże nadawca mówi szczerze. Spór intenralizm-eksternalizm na gruncie teorii aktów mowy skonceptualizował Hanish (2009). Zdefiniował on ten spór w następujący sposób: jeżeli warunki czynności mowy są determinowane przez stany mentalne mówiącego, to jest to stanowisko internalistyczne. Natomiast jeżeli warunki dotyczą jedynie tego, jaki ,świat zewnętrzny” ma być, to jest to stanowisko eksternalistyczne.
} 
Searle i Vanderveken $(1985)^{9}$ wymieniają trzy rodzaje warunków, jakie ma spełniać akt mowy: 1) warunki zawartości zdaniowej (propositional content conditions), 2) warunki przygotowawcze (preparatory conditions), 3) warunki szczerości (sincerity conditions). Searle (1987) do tych warunków dodaje jeszcze jedną grupę: 4) warunki istotne (essentials consition). Warunki te są w klasyfikacji aktów mowy pogrupowane w ramach reguł, analogicznie nazwanych. Nazywa je więc: 1) regułą zawartości zdaniowej, 2) regułą przygotowawczą, 3) regułą szczerości oraz 4) regułą istotną. Określają one warunki wykonania pewnego aktu ze względu na cechy danego warunku. Pierwsza reguła dotyczy wymagań syntaktycznych i semantycznych danego aktu mowy (na przykład tego, że wykonywać konkretny akt mowy można jedynie za pomocą zdania albo tego, że przedmiotem rozkazu może być tylko przyszły stan rzeczy). Druga reguła określa presupozycje ${ }^{10}$ dla danego aktu (na przykład rozkazać można tylko to, co jest możliwe do wykonania). Z trzecią regułą wiąże się konieczność wystąpienia u wykonawcy pewnego stanu mentalnego (na przykład, według Searle’a, dziękować za X można wtedy, gdy odczuwa się wdzięcznośćc ${ }^{11}$ za X). Reguła czwarta dotyczy społecznego odbioru wykonywanego aktu mowy. Społecznie odbiera się dane słowa jako wykonywanie czynności mowy określonego typu (na przykład wypowiedzenie słów „przebaczam ci” uchodzi za przebaczenie). Wygłoszenie pewnych słów przy spełnieniu warunków kryjących się pod omówionymi regułami jest równoznaczne $\mathrm{z}$ dokonaniem fortunnego aktu mowy określonej mocy illokucyjnej.

Jest oczywiste, że istnienie tych reguł musi wyprzedzać dokonanie jakiegokolwiek fortunnego aktu mowy. Wedle Searle’a reguły te mają charakter konwencjonalny.

\footnotetext{
${ }^{9}$ Wcześniej Searle (1987) wyróżnił dla omawianej obietnicy siedem warunków: a) warunek normalności, b) warunki zawartości zdaniowej, c) warunki przygotowawcze, d) warunek szczerości, e) warunek istotny, f) warunek ekspresji intencji, g) warunek domknięcia [nazwy warunków a), f) i g) pochodzą ode mnie - B.B.]

${ }^{10}$ Alston (2000) określa ten typ warunków jako ,pojęciowo konieczne warunki” (conceptually necessary conditions). Takie nazwanie tych warunków podkreśla fakt, że bez ich zajścia sam akt mowy byłby niemożliwy pojęciowo. Przykładem może być rozkaz wydany przez szeregowego żołnierza generałowi. W tym przypadku taka sprzeczność pojęciowa wiązałaby się zapewne z poważnymi konsekwencjami dyscyplinarnymi. Konsekwencją niezajścia pojęciowo koniecznych warunków jest wstępna niemożliwość wykonania aktu mowy. Alston opisuje je w następujący sposób: „To są warunki, bez których [dany akt mowy - B.B.] nie może zaistnieć [...]. Odroczenie posiedzenia zawiera w sobie to, że właśnie odbywa się sesja tego posiedzenia. [...] To są ogólne warunki dla wykonania [danego aktu mowy - B.B.] przez kogokolwiek w określonym czasie. Nie mają one specjalnego odniesienia do zdolności [wykonawcy aktu - B.B.], czy taki akt potrafi wykonać, ani do okoliczności towarzyszących wypowiedzi” (Alston, 2000, s. 93, przypis 8).

${ }^{11}$ Nie chodzi tu jednak o rzeczywistą wdzięczność, ale o to, że wykonanie tego aktu mowy uchodzi za wdzięczność (por. Searle, 1987, s. 83, gdzie pisze: „by uwzględnić obietnice nieszczere [...] [należy stwierdzić, że B.B.] mówiący bierze odpowiedzialność za to, że ma intencję [wykonania przedmiotu obietnicy - B.B.], zamiast stwierdzenia, że faktycznie ją ma”).
} 


\title{
3.3. Nonkonwencjonalizm w teorii aktów mowy
}

\subsubsection{Akty komunikacyjne i stricte konwencjonalne}

Poniżej zostanie opisane stanowisko nonkonwencjonalistyczne. Stanowisko to zaprezentował Strawson:

\begin{abstract}
Możemy bez wahania wyobrazić sobie warunki, w których wypowiedzenie słów „Nie idź!” mogłoby być poprawnie opisane nie jako prośba, rozkaz, ale jako błaganie. Nie chcę zaprzeczać temu, że mogą być jakieś konwencjonalne postawy czy procedury dla błagania: ktoś może, na przykład klęknąwszy, podnieść ramiona i powiedzieć „błagam cię”. Jednakże chciałbym zaprzeczyć temu, że akt błagania może być dokonany tylko w zgodzie z jakimiś takimi konwencjami. Co powoduje, że Iksa wymiana zdań z Igrekiem będąca błaganiem, aby nie szedł, jest czymś - wystarczająco skomplikowanym, bez wątpienia - powiązanym z położeniem Iksa, postawą wobec Igreka, sposobem i obecną intencją. [...] [Uważanie, że akty mowy muszą być dokonywane według określonej konwencji-B.B.] jest jak zakładanie, że nie byłoby romansem to wszystko, co nie jest zgodne z linią ustanowioną w Roman de la rose. (Strawson, 1964, s. 444; thumaczenie moje)
\end{abstract}

Koncepcja komunikacyjnych aktów mowy Strawsona opiera się więc na zanegowaniu użycia dużego kwantyfikatora przy wskazywaniu na konwencjonalizm aktów mowy. Nie jest tak, że do każdego rodzaju aktów mowy jest przypisany pewien zbiór reguł, które określić można jako konwencję. Oczywiście, mówi Strawson, istnieją takie skonwencjonalizowane akty mowy, których przykładami mogą być wszelkie akty mowy dokonywane na gruncie instytucji prawnych, na przykład małżeństwa (Strawson, 1964, s. 443). Strawson przyjmuje, że konwencjonalne jest z konieczności znaczenie aktu mowy na poziomie badania lokucji (czyli treści propozycjonalnej, sądu), natomiast konwencjonalnie nie jest zdeterminowana sama illokucja.

Strawson wyróżnia więc dwa rodzaje aktów: 1) komunikacyjne oraz 2) stricte konwencjonalne. W skrócie koncepcja ta dotyczy sposobu, w jaki komunikujemy swoje stany mentalne, które mają wywierać pewne skutki (illokucyjne i perlokucyjne). W związku z tym danej wypowiedzi muszą dotyczyć odpowiednie stany mentalne nadawcy i odbiorcy, które składają się na cztery intencje komunikacyjne, a sama moc illokucyjna musi być trafnie rozpoznana przez odbiorcę wypowiedzi (Strawson, 1964, s. 459). Do analizy komunikacyjnych aktów mowy stosuje tak zwane iteracyjne ujęcie intencji komunikacyjnej Grice'a (1957; zob. też Witek, 2012, s. 85), modyfikując jego koncepcję z n a c z e n ia mó w cy.

\subsubsection{Intencja komunikacyjna}

Znaczenie mówcy w pierwotnej koncepcji Grice’a składa się z trzech elementów: a) intencji, aby wywołać pewien efekt u odbiorcy; b) intencji, aby intencja (a) została rozpoznana przez odbiorcę; oraz c) intencji, aby ten efekt u odbiorcy był powodowany przynajmniej po części poprzez rozpoznanie przez niego intencji (a). Strawson (1957, s. 447) dodaje do tego kolejny warunek: d) dodatkowa, wcześniejsza intencja, by odbiorca rozpoznał intencję (b). Ten 
nowy element pozwala mu dokonać ostatecznej konstatacji, że „to, czy jest ona [intencja (a) - B.B.] rozpoznana, jest czymś, co leży po stronie odbiorcy" (Strawson, 1957, s. 459).

Mówić coś z określoną mocą illokucyjną to jednocześnie posiadać odpowiednią intencję (Strawson, 1964, s. 106) i chcieć wywoływać poprzez jej zakomunikowanie określoną reakcję odbiorcy.

Akty komunikacyjne w rozumieniu Strawsona nie są konwencjonalne, jednak są podatne na konwencjonalizację. Gdy jakiś schemat postępowania okazuje się skuteczny do wyrażenia złożonego stanu mentalnego, to wywołanie reakcji u odbiorcy staje się zwyczajowym sposobem osiągania danego celu (na przykład poprzez skonwencjonalizowane performatywy).

\subsubsection{Podsumowanie stanowisk}

Podsumowując oba stanowiska, należy podkreślić pewne cechy, które przypisują ich reprezentanci aktom mowy. Stanowisko konwencjonalistów opiera się na tezie, że akt mowy jest wynikiem konwencji, reguły, zwyczaju - językowego, społecznego, prawnego. Moc illokucyjna zależy tylko i wyłącznie od tych reguł. Osoba wypowiadająca oraz odbiorca wypowiedzi są uwikłani w pewną grę językową, tylko internalizacja reguł czy konwencji pozwala im na rozpoznanie mocy illokucyjnej wypowiedzi i odpowiednią reakcję na tę wypowiedź.

Stanowisko antykonwencjonalistyczne neguje tezę, że każdy akt mowy jest konwencjonalny. Reprezentanci tego stanowiska twierdzą, że moc illokucyjna aktu mowy zależy od specyficznej relacji, w jakiej pozostają mówiący oraz odbiorca. Podstawowym celem wypowiedzi jest skuteczne, zapewnione przedsięwziętymi środkami werbalnymi, wywarcie wpływu na odbiorcę poprzez zakomunikowanie mu swojej intencji.

\subsection{Obowiązywanie jako skutek illokucyjny}

Odwołajmy się teraz do dwóch pytań zadanych w poprzedniej sekcji: 1) czy może zaistnieć akt mowy bez poprzedniej konwencji oraz 2) jeżeli tak, to czy prawo jest tego typu aktem mowy.

Akt mowy Lexa brzmiał następująco:

Aby rozwiązać tę sytuację, proponuję następujący sposób postępowania: [1] Przedstawię zbiór reguł, które dotyczyć będą naglących obecnie spraw. Będziecie wiedzieć kiedy stworzyłem regułę, gdy [2] wydam rozkaz, [3] siedząc pod wielką palmą na wiejskim rynku. (Shapiro, 2011, s. 37; wyróżnienie i tłumaczenie moje)

W kontekście wcześniejszych rozważań można potraktować samą wypowiedź Lexa jako akt mowy mający ustanawiać społeczną konwencję dla przyszłych aktów mowy, które z kolei potraktować możemy jako akty tworzące prawo. W formie bardziej kanonicznej brzmiałoby to: „Normuję, że X”. Lex dokonał więc, roboczo mówiąc, aktu mowy no r m ow a n ia. Ten akt mowy ma zatem stwarzać regułę wtórną, a w szczególności regułę 
uznania (i zmiany) w rozumieniu Harta. Poprzez wygłoszenie tych słów Lex chciał dokonać aktu ustanowienia instytucji powstawania prawa, przedstawiając sposób, w który dokonywać się będzie tworzenie i zmiana prawa. Reguła ta ma postać: „Cokolwiek powiem w tym-a-tym miejscu, będzie prawem". Dokonując tego aktu, Lex stworzył możliwość dokonywania innych aktów mowy, które wprowadzać będą reguły pierwszego rzędu. Skutkiem illokucyjnym takiego aktu mowy ma być obowiązująca norma prawa.

\subsubsection{Normowanie jako realizacja konwencji}

Według klasyfikacji Searle’a (1976) wypowiedź Lexa najbardziej zbliżona jest do tak zwanych dyrektyw ${ }^{12}$. Są to akty mowy, których illokucyjnym skutkiem ma być skłonienie odbiorcy do zrobienia czegoś. Treścią tego typu aktów mowy jest wskazanie na kierunek dopasowania świata do słowa (ang. world-to-word direction of fit; Searle, Vanderveken, 1985). Owo dopasowanie jest właśnie elementem normatywnym tego typu aktów. Spróbuję przedstawić teraz zarys warunków dla n o r m o w a n i a Le x a, jakie można zrekonstruować na podstawie histori ${ }^{13}$. Zakładam, że odbiorcą tego aktu mowy są wszyscy mieszkańcy wioski, a X reprezentuje określony sposób postępowania.

1) Warunek zawartości zdaniowej: $X$ dotyczy przyszłych zachowań członków społeczności, a zachowania te są możliwe.

2) Warunek przygotowawczy:

a) Nie jest oczywiste dla samych mieszkańców i Lexa, że mieszkańcy będą postępowali w sposób X w normalnym toku rzeczy.

b) wersja 1 (według Shapiro): Lex jest dla mieszkańców autorytetem (epistemicznym).

b) wersja 2 (według Phila): Lex jest dla mieszkańców autorytetem deontycznym.

c) Lex wierzy, że spełnienie X spowoduje, że życie społeczne będzie lepsze.

3) Warunek szczerości: Lex chce, by mieszkańcy postępowali według reguły, którą wypowiedział.

4) Warunek istotny: wypowiedź Lexa liczy się jako próba wpłynięcia na mieszkańców, by postępowali w sposób X.

\footnotetext{
${ }^{12}$ Należą do nich między innymi pytania, rozkazy, polecenia, prośby czy również rady i dozwolenia (zob. Searle 1976, s. 11).

${ }^{13}$ Searle (1969) określił następujące warunki dla polecenia (wyliczenie odwołuje się do części 3.2 .3 niniejszej pracy): 1) przyszły czyn X słuchającego(S), 2): 2a) S jest w stanie X i mówiący (M) wierzy, że $S$ jest w stanie $\mathrm{X}, 2 \mathrm{~b})$ nie jest oczywiste dla $\mathrm{M}$ i S, że S zrobi A sam z siebie w normalnym toku zdarzeń, 2c) M jest autorytetem dla $\mathrm{H}$; 3 ) S chce, żeby H zrobił X; 4) wypowiedź liczy się jako próba wpłynięcia na S, by zrobił X ze względu na to, że $\mathrm{M}$ jest autorytetem dla $\mathrm{H}$.
} 
Z perspektywy konwencjonalistycznej stwierdzić można, że fortunność aktu mowy Lexa zależy od tego, czy Lex realizował pewną konwencję, która była zwyczajem w danej społeczności. Lex pod względem wcześniej wskazanych warunków: warunek 1) - wygłosił zdanie o przyszłości (to znaczy treść propozycjonalna jego sądu dotyczyła przyszłych stanów rzeczy); warunek 3) - szczerze chciał ustanowić nową regułę, która pozwoli mu regulować najważniejsze dla wioski kwestie; warunek 4) - spełnił warunki istotne, gdyż członkowie wioski, włączając w to Phila, zrozumieli, iż poprzez te słowa chce wprowadzić nową konwencję. Stanowisko Phila, jak się wydaje, kwestionuje spełnienie jednego $\mathrm{z}$ warunków dla fortunności aktu mowy Lexa, a mianowicie warunku, że Lex jest autorytetem deontycznym dla społeczności.

Wedle Phila Lex nie może ustanawiać prawa bez wcześniejszej reguły upoważniającej go do robienia tego (to znaczy reguły przyznającej mu autorytet deontyczny). Nawet jeżeli dotychczas członkowie społeczności ze względu na wiek i doświadczenie Lexa kierowali do niego skargi i to on pomagał ustalać sposoby koordynacji życia społecznego (uważali go za autorytet w zakresie tego, co będzie dla nich najlepszym planem), to jednak nie uważali, że są zobowiązani do posłuszeństwa Lexowi, gdyż nie uznawali się za jego poddanych $^{14}$. Phil wskazuje, że nikt w wiosce nie jest wyposażony w autorytet deontyczny. Relacje społeczne w wiosce nie są hierarchiczne, a więc nie istnieje norma nakazująca dawać posłuch słowom Lexa. Lex jest co najwyżej autorytetem epistemicznym. Dodatkowo, oparcie się na autorytecie epistemicznym Lexa wyjaśnia jedynie powstanie dobrego prawa. Czy gdyby pierwszy rozkaz wypowiedziany przez Lexa, zgodnie ze sformułowaną przez niego regułą uznania, zobowiązywałby do zakwaszenia gleby całej wioski lub wybicia całego bydła, to czy członkowie społeczności uznaliby ten rozkaz za wiążący?

Z drugiej strony, ludzie w jakiś sposób kooperują, komunikują się i podejmują decyzje w sytuacji przedprawnej - tak jest przynajmniej w historii opowiadanej przez Shapiro. Skoro istnieje ustalona forma kooperacji (na przykład podejmowanie decyzji w sprawie dziesięcin), to zapewne istnieją pewne formy jej egzekwowania. Z punktu widzenia konwencjonalizmu w teorii aktów mowy można bronić tezy, że właśnie te podstawowe, nieskodyfikowane formy kooperacji stanowią fundament dla aktu mowy Lexa. W historii o Lexie i Philu jest położony akcent na prawo jako formę planowania, gdyż Shapiro rozbudowuje swoją koncepcję, właśnie opierając się o tezę, że prawo jest formą planu. Patrząc jednak na akt mowy Lexa jedynie z perspektywy pragmatyki lingwistycznej, jego zachowanie jest zrozumiałe dla innych członków, ponieważ poprzez konwencjonalne formy współpracy przedprawnej potrafią wyobrazić sobie, jak w praktyce wyglądać będzie realizacja tego, co proponuje Lex.

\footnotetext{
${ }^{14}$ Twierdzę, że jest to wersja Shapiro, gdyż najbardziej zgadza się z jego planowa teorią prawa. Jak wskazuje Gizbert-Studnicki (2015): „rozwiązanie Shapiro polega na odnalezieniu ostatecznych źródeł normatywności w normach racjonalności instrumentalnej. Prawo jest na gruncie teorii Shapiro planem, a więc faktem społecznym [...]. Władza (authority) pojęta jako zdolność do stwarzania racji do działania jest przypisana wykonawcy planu przez normy racjonalności instrumentalnej, zastosowane do realizacji planu, gdyż w braku takiej władzy plan utraciłby społeczny sens" (s. 36-37).
} 


\subsubsection{Normowanie $\mathrm{z}$ perspektywy nonkonwencjonalizmu}

Być może odwołanie się do reguły przypisującej Lexowi autorytet deontyczny nie jest potrzebne. Lex dokonał aktu mowy, który potem wszyscy respektowali - skutek illokucyjny został osiągnięty, gdyż reguły wydane na podstawie reguły uznania wprowadzonej przez Lexa zostały uznane za obowiązujące.

Wskazuje się, iż najczęściej niekonwencjonalnymi aktami mowy są akty komunikacyjne bądź te stricte oparte na chęci wyrażenia pewnej intencji (poprzez którą chce się wywrzeć wpływ na odbiorcę). Moc illokucyjna nie jest zdeterminowana konwencjonalnie, lecz zależy od rozpoznania jej przez odbiorcę komunikatu. Przy propozycji Lexa można zastanowić się, jaką moc illokucyjną przypisywał on swojej wypowiedzi. Zauważymy, iż w częściach (1) oraz (2) swojej wypowiedzi Lex posługuje się słowami „reguła” oraz „rozkaz”. Nie chce on jednak utożsamiać rozkazu z prawem. Jego wypowiedź z przytoczonej historyjki jest na poziomie metaprawnym, czyli jego propozycja dotyczy przyszłych reguł i rozkazów. Samą wypowiedź można zanalizować jako propozycję wprowadzenia pewnej konwencji. Konwencja ta jest o tyle jednak niecodzienna, iż zostaje wyraźnie wyeksplikowana.

Wypowiedź Lexa jest pewną propozycją: potraktujmy pewne moje przyszłe wypowiedzi, które nazywamy rozkazami (założenie mocy illokucyjnej), jako wiążące reguły pod warunkiem, że wygłoszę je pod palmą. Taka postać tej wypowiedzi przypomina więc Searle'owską kanoniczną formę dla reguł konstytutywnych: X uchodzi za Y w kontekście C. Performatywność wypowiedzi Lexa polega na tym, że za pomocą tych słów dokonuje on wprowadzenia właśnie tej reguły konstytutywnej.

Można argumentować, jak wskazałem, że konwencjonalizm potrzebowałby w tym miejscu kolejnego kroku wstecz, gdyż wymagałby wskazania reguły upoważniającej Lexa do dokonania takiego aktu mowy ${ }^{15}$. Nonkonwencjonalizm wymaga dla fortunności tej illokucji jedynie tego, aby odbiorcy zrozumieli jego przekaz i ze względu na niego w odpowiedni sposób reagowali. Nie stoi jednak w sprzeczności z nonkonwencjonalizmem to, że po czasie prawo ma charakter konwencjonalny (poprzez regułę konstytutywną wprowadzoną przez Lexa).

\subsection{Dlaczego Aporia Phila nie dotyczy nonkonwencjonalistów?}

Spójna z perspektywy obu stanowisk jest następująca konstatacja: prawo ma charakter konwencjonalny, składa się z samoodnoszących się do siebie reguł (reguły I i II stopnia Harta). Sporne pozostaje jednak to, jaką formę - konwencjonalną czy nie - ma „wypowiedź Lexa", stojąca genetycznie u podstaw tych reguł. Sama analiza formy pokazuje, że wypowiedź ma formę reguły konstytutywnej (perspektywa semantyczna), sama jednak moc illokucyjna jest trudna do wyodrębnienia i zależy już od silnych presupozycji na temat konwencjonalnego charakteru języka.

\footnotetext{
${ }^{15}$ Być może związki Harta z Austinem stanowiły o jego tak silnym przekonaniu, że prawo musi mieć ,„pierwszą przyczynę" w postaci reguł II stopnia, w tym reguły uznania - przyjmował za nim stanowisko konwencjonalistyczne.
} 
Warto podkreślić, że perspektywa konwencjonalna doprowadzić może do dwóch tez: albo 1) prawo istniało zanim Lex wygłosił swoją propozycję, albo 2) należałoby przyjąć tezę redukcjonistyczną - odwołując się bezpośrednio do jakiejś wcześniejszej konwencji, prawo można zredukować w pełni do innych form kooperacji społecznej. Skoro Lex realizował jakąś konwencjonalną praktykę, którą dopiero poprzez dokonanie przez niego aktu mowy nazywamy prawem, to prawo ma źródło w innych, mniej rozwiniętych zwyczajach społecznych. Argument Phila, jeżeli jest zasadny, dotyczy właśnie braku istnienia konwencji, do której mógłby odwołać się Lex. Jeżeli nie istnieje taka konwencja, to wypowiedź Lexa była jedynie pewnym wydarzeniem, które nie zaowocowało żadną zmianą rzeczywistości. Lex, według Phila, nie dokonał fortunnego aktu mowy przez niespełnienie warunku - jego akt nie był aktem udanym (w znaczeniu wcześniej wskazanym).

Argument Phila nie dotyka natomiast aktu Lexa w przypadku przyjęcia tezy nonkonwencjonalistycznej. Na wystąpienie omówionych w punkcie 3.3.2. intencji (a-d) wskazuje fakt, iż wszyscy - także Phil - zro z u m i e li, co Lex chce osiągnąć i wyrazili chęć podporządkowaniu się jego propozycji. Argument Phila dotyczy braku konwencji, która, jak argumentują nonkonwencjonaliści, nie jest zawsze potrzebna do osiągnięcia skutku illokucyjnego. Argument Phila nie wskazywałby więc, iż illokucja Lexa jest niefortunna. Po pierwsze, wszyscy zrozumieli intencje; po drugie, zachodził skutek interakcyjny, to znaczy, ze względu na słowa Lexa ludzie zachowywali się w sposób, który był treścią jego intencji.

\section{Czy Aporia Phila jest w ogóle aporią? Kazus Pierwszego Pytającego}

Co jednak z obowiązywaniem samej reguły, która Lexowi, kimkolwiek by nie był pierwszy legislator, miałaby dać uprawnienie do ustanowienia pierwszych reguł prawnych? Jak wskazałem, skuteczna komunikacja poprzez akty mowy opiera się o pewną społeczną praktykę. Są nimi bądź zawarte implicite w praktyce społecznej konwencje (teza o konwencjonalnym źródle aktów mowy), bądź skuteczne sposoby wyrażania swoich stanów mentalnych (teza nonkonwencjonalna, oparta o tezę o komunikacyjnej funkcji aktów mowy). Jak wskazałem wyżej, dotychczasowe analizy Aporii Phila (na przykład w wykonaniu Harta czy ogólnie pozytywistów) opierały się na znalezieniu pewnej konwencji. Potraktowanie Lexa jako Pierwszego Legislatora, a samych jego słów jako aktu mowy, pozwoliło na umieszczenie problemu w kontekście sporu o genezę aktów mowy. Wykazałem, że z perspektywy nonkonwencjonalizmu w teorii aktów mowy Aporia Phila nie stanowi problemu. Aporia ta opiera się na ukrytym założeniu, że akty mowy mają charakter konwencjonalny.

W przeciwieństwie jednak do teorii prawa, w teorii aktów mowy nie poszukuje się najczęściej pierwszych przyczyn. Nie ma pytania o to, dlaczego, od kiedy i na jakiej właściwie podstawie rozkazujemy sobie, prosimy, przekazujemy sobie pewne informacje. Tak po prostu jest. Jeżeli chcemy wnieść coś do debaty filozoficznej, powinniśmy dokonać adekwatnego opisu pewnych zjawisk, które de facto występują, a nie próbować skupiać się na ewentualnych lukach w wyjaśnieniu ich genezy. Czy więc zarzut Phila był w tym kontekście adekwatny? 
Według mnie błąd Phila (albo ogólniej: teorii i filozofii prawa) polega na domniemaniu aporetyczności zachowania, które w gruncie rzeczy aporetyczne nie jest. Problem wskazany przez Phila przypomina też słynny paradoks kłamcy: czy wieczny kłamca, mówiąc, że teraz kłamie, rzeczywiście kłamie, czy mówi prawdę? Aporie te od zawsze przyczyniały się do rozwoju filozofii, jednak z punktu widzenia zdrowego rozsądku wydają się problemami błahymi. Analogia ta nie miała jednak na celu zbagatelizowania tego problemu, ale miała wskazać, że być może przeformułowanie problemu spowoduje, że aporetyczność zniknie. Proponuję zastanowić się nad tym, czy wątpliwości Phila są zasadne, gdy przyjmie się, że próbuje poszukiwać reguły, której istnienia wskazać się nie da.

Zachowania komunikacyjne w ramach mniejszych i większych społeczności są w większości ad hoc. Chodzi w nich o skuteczne przekazanie pewnych myśli, stanów nastawieniowych czy propozycjonalnych. Język jest jedynie narzędziem do realizacji tych celów. Lex nie musiał odwoływać się do żadnej reguły, podobnie jak język nie wymaga do mówienia ciągłego potwierdzania przez nadawcę tego, $\mathrm{z}$ jakich reguł korzysta.

Analiza języka i komunikacji przebiega poprzez ich wyjaśnienie, a nie próbę analizy, jak mogły wyglądać pierwsze formy na przykład aktów mowy. Jeżeli skłania nas do dyskusji Aporia Phila, czemu nie skłania do równie burzliwej dyskusji hipotetyczna sytuacja, w której ,pierwszy pytający” zadawszy pytanie swojemu rozmówcy ${ }^{16}$ i uzyskawszy od niego odpowiedź, następnie słyszy od osoby trzeciej: „ale na mocy jakiej reguły chcesz uzyskać odpowiedź?” W sytuacji, w której znajduje się „pierwszy pytający”, nie istnieje żadna taka reguła ani praktyka, aby na to, co nazywamy „,pytaniem”, należało zareagować „odpowiedzią”. Można zadać takie pytanie, jednak po co? Co sprawia, że akt mowy „normowania” jest wyjątkiem i filozofowie prawa starają się uzasadnić ,„pierwsze normodawstwo"? To pytanie pozostawiam otwartym.

Właściwa postawa Lexa powinna być inna. Powinien zaakceptować fakt, że nie ma takiej reguły oraz zadać pytanie: na mocy czego doprowadził do sytuacji, w której wszyscy mieszkańcy chcą uznawać jego słowa wygłoszone pod palmą za reguły prawne? Problem ten to wskazane wcześniej przejście od autorytetu epistemicznego do deontycznego.

Metoda ta została wyeksplikowana przez Hegla (1969) jako zadanie ogólnej filozofii: „Kiedy filozofia o szarej godzinie maluje swój świt, wtedy pewne ukształtowanie życia już się zestarzało, a szarością o zmroku nie można niczego odmłodzić; można tylko coś poznać. Sowa Minerwy wylatuje dopiero z zapadającym zmierzchem." (Hegel, 1969, s. 21; wyróżnienie moje). Teoretycy prawa, tacy jak Phil, próbują jednak wypuścić Sowę Minerwy już o świcie. Filozofowie zajmujący się teorią aktów mowy, do których zaliczyłbym teoretyków prawa zajmujących się omawianym problemem, badają zjawisko już występujące. Fakt występowania takich zjawisk jak py ta n i e, no r mo w a n i e czy ro z k a z y w a n i e jest równie realny jak fakt występowania kamieni. Kompetencja do uchwalania reguł nie musi więc pociągać za sobą istnienia czasowo pierwszej

\footnotetext{
${ }^{16}$ Na przykład w formie wyraźnej illokucji: „Odpowiedz mi proszę, co jest sensem życia?”.
} 
normy prawnej. W związku z tym Amselek postawił tezę, iż w gruncie rzeczy reguła uznania ma charakter podobny do praw w sensie nauk ścisłych (scientific law).

Najważniejszą rzeczą, za pomocą której teoria aktów mowy wpłynęła na filozofię prawa, jest to, że reguły postępowania [rules of conduct] oraz reguly, które konstytuują normy prawne, jak reguły uznania, które są prawami w sensie nauk ścisłych [like the recognitive rules which are scientific laws], formują jeden akt, jedne intencjonalne postępowanie, jedną operację mentalną. (Amselek, 1988, s. 219; tłumaczenie moje)

Reguła uznania dotyczy więc faktycznego społecznego postępowania. Gdybyśmy znajdowali się w świecie, w którym rzeczywiście prawo pochodzi od jakiejś jednej, poznawalnej istoty wyższej, to reguła uznania miałaby inną treść. Podobnie w przypadku, gdyby w rzeczywistości prawa grawitacji były inne - na przykład, jak to twierdził Arystoteles, wszystkie rzeczy byłyby z ziemi, a zgodnie z jego fizyką rzeczy z ziemi przyciągane są przez ziemię - prawa natury miałyby inną treść. W obu przypadkach tak jednak nie jest. Potrzeba wykazywania istnienia ,pierwszej reguły” jest w związku z tym iluzoryczna. Czy Aporia Phila jest tak prosta?

\section{Bibliografia}

Alston, W. P. (1991). Searle on illocutionary acts. W: E. LePore, R. Van Gulick (red.) John Searle and his critics (s. 57-80). Oxford, UK: Blackwell.

Alston, W. (2000). Illocutionary acts and sentence meaning. New York, NY: Cornell University Press.

Amselek, P. (1988). Philosophy of law and the theory of speech acts. Ratio Juris, 1, 187-223. https://doi.org/10.1111/j.1467-9337.1988.tb00015.x

Anscombe, G. (1958). On brute facts. Analysis, 18(3), 69-72. https://doi.org/10.2307/3326788

Austin, J. L. (1993). Mówienie i poznawanie: Rozprawy i wykłady filozoficzne (B. Chwedeńczuk, tłum.). Warszawa: Wydawnictow Naukowe PWN. (Oryginalna praca wydana w 1978).

Bach, K. (2005). Context ex machina. W: Z. G. Szabó (red.), Semantics versus pragmatics (s. 15-44). Oxford, UK: Oxford University Press.,

Bach, K. (2006). Speech acts and pragmatics. W: M. Devitt, R. Hanley (red.), The Blackwell guide to the philosophy of language (s. 147-167). Malden, MA: Blackwell Publishing.

Bird, A. (2002). Illocutionary silencing, Pacific Philosophical Quarterly, 83(1), 1-15.

Chiassoni P. (2013), Ruling platitudes, old metaphysics, and a few misunderstandings about legal positivism. W: D. Canale, G. Tuzet (red.), The planning theory of law: A critical reading. Dordrecht, Holandia: Springer.

Cohen, L. J. (1964). Do illocutionary forces exist? The Philosophical Quarterly, 14(55), 118-137. https://doi.org/10.2307/2955549

Dyrda, A. (2013). Konwencja u podstaw prawa: Kontrowersje pozytywizmu prawniczego. Warszawa: Wolters Kluwer. 
Gizbert-Studnicki, T., Grabowski, A. (2000). Istnienie, prawdziwość i logika norm - jeszcze o nielingwistycznej koncepcji normy. W: J. Hartman (Ed.), Filozofia i logika: W stronę Jana Woleńskiego (s. 208-224). Kraków: Aureus.

Gizbert-Studnicki T. (1973). Stwierdzenie jako akt mowy. Studia filozoficzne, 1973(3), 84-97.

Gizbert-Studnicki T. (1980). Czym nie są wypowiedzi performatywne. Studia filozoficzne, 1980(8), $121-129$.

Gizbert-Studnicki T. (1975). O nieważnych czynnościach prawnych w świetle koncepcji czynności konwencjonalnych. Państwo i Prawo, 1975(4), 70-82.

Gizbert-Studnicki, T. (2016). Metafizyka pozytywizmu prawniczego. Principia, 61-62, 19-40. https://doi.org/10.4467/20843887PI.15.002.5531

Green, M. (2000). Illocutionary force and semantic content. Linguistics and Philosophy, 23(5), 435-473. https://doi.org/10.1023/A:1005642421177

Green, M. (2007a). Speech acts. W: E. N. Zalta (red.), The Stanford encyclopedia of philosophy (Fall 2017 edition). Pobrano 20 października 2017 z: https://plato.stanford.edu/archives/sum2015/entries/speech-acts/

Green, M. (2007b). How do speech acts express psychological states? W: S. Tsohatzidis (red.), John Searle's philosophy of language: Force, meaning and mind (s. 267-284). Cambridge, UK: Cambridge University Press. https://doi.org/10.1017/CBO9780511619489.013

Green, M. S. (2009). Speech acts, the handicap principle and the expression of psychological states. Mind \& Language, 24(2), 139-163. https://doi.org/10.1111/j.1468-0017.2008.01357.x

Green, M. (2010). Speech acts. W: T. O'Connor, C. Sandis (red.), A companion to the philosophy of action (s. 58-66). Hoboken, NJ: Wiley-Blackwell.

Grice, H. (1957). Meaning. The Philosophical Review, 66(3), 377-388. https://doi.org/10.2307/2182440

Grice, H. P. (1975). Logic and conversation. W: P. Cole, J. Morgan (red.), Syntax and semantics: Vol. 3 (s. 41-58). New York, NY: Academic Press.

Harnish R. M. (2005). Commitments and speech acts. Philosopica, 75, 11-45.

Harnish R. M. (2009). Internalism and externalism in speech act theory. Lodz Papers in Pragmatics, 5(1), 9-31. https://doi.org/10.2478/v10016-009-0001-2

Hart, H. L. (1998). Pojęcie prawa (J. Woleński, thum.). Warszawa: PWN.

Hart, H. L. (2001). Eseje z filozofii prawa (J. Woleński, thum.). Warszawa: Dom Wydawniczy ABC.

Kissine, M. (2013). From utterances to speech acts. Cambridge, UK: Cambridge University Press. https://doi.org/10.1017/CBO9780511842191

Kurzon, D. (1986). It is hereby performed... Explorations in legal speech acts. Amsterdam, Kolandia: Benjamins.

Liu, W., Liu, S. (2007). Illocutionary and perlocutionary acts in Chinese judge's attached discourse. Lodz Papers in Pragmatics, 3(1): 137-144. https://doi.org/10.2478/v10016-007-0009-4

Millikan, R. (1998). Language conventions made simple. The Journal of Philosophy, 95(4), 161-180. https://doi.org/10.2307/2564683 
Osmola, S., Załuski, W. (2017). "Is" and "Ought" in Hume's and Kant's Philosophy. W: M. Sellers, S. Kirste (red.), Encyclopedia of the philosophy of law and social philosophy. Dordrecht, Holandia: Springer. https://doi.org/10.1007/978-94-007-6730-0_225-1

Opałek, K., Woleński, J. (1987). Is, ought, and logic. ARSP: Archiv Für Rechts- Und Sozialphilosophie / Archives for Philosophy of Law and Social Philosophy, 73(3), 373-385.

Opałek, K., Woleński J., (1988). Logika i interpretacja powinności. Krakowskie Studia Prawnicze, $21,13-29$.

Poggi, F. (2013). The Possibility Puzzle and legal positivism. W: D. Canale, G. Tuzet (red.), The planning theory of law: A critical reading. Dordrecht, Holandia: Springer.

Rawls, J. (1955). Two concepts of rules. The Philosophical Review, 64(1), 3-32. https://doi.org/10.2307/2182230

Sbisà, M. (2002). Speech acts in context. Language \& Communication, 22(4), 421-436. https://doi.org/10.1016/s0271-5309(02)00018-62007

Sbisà, M. (2007). How to read Austin: Pragmatics. Quarterly Publication of the International Pragmatics Association (IPrA) Pragmatics, 17(3), 461-473. https://doi.org/10.1075/prag.17.3.06sbi

Searle, J. R. (1968). Austin on locutionary and illocutionary acts. The Philosophical Review, 77(4), 405. https://doi.org/10.2307/2183008

Searle, J. R. Indirect speech acts. W: P. Cole, J. Morgan (red.), Syntax and semantics: Vol. 3 (s. 59-82). New York, NY: Academic Press.

Searle, J. (1976). A classification of illocutionary acts. Language in Society, 5(1), 1-23. https://doi.org/10.1017/S00474045000068371977

Searle, J. (1983). Intentionality. Cambridge, UK: Cambridge University Press.

Searle, J. R. (1987). Czynności mowy: Rozważania z filozofii języka (B. Chwedeńczuk, tłum.). Warszawa: Instytut Wydawniczy Pax.

Searle, J. (2005). What is an institution? Journal of Institutional Economics, 1(1), 1-22. https://doi.org/10.1017/S1744137405000020

Shapiro, S. J. (2011). Legality. Cambridge, MA: Harvard University Press.

Shuy, R. W. (2014). The language of bribery cases. New York, NY: Oxford University Press.

Smith, B. (1990). Towards a history of speech act theory. W: A. Burkhardt (red.) Speech acts, meanings and intentions: Critical approaches to the philosophy of John R. Searle (s. 29-61). Berlin, Niemcy: de Gruyter.

Stenius, E. (1969). Mood and language-game. W: J. W. Davis, D. J. Hockney, W. K. Wilson, Philosophical Logic (s. 251-271). https://doi.org/10.1007/978-94-010-9614-0_18

Strawson, P. F. (1964). Intention and convention in speech acts. The Philosophical Review, 73(4), 439. https://doi.org/10.2307/2183301

Witek, M. (2011). Spór o podstawy czynności mowy. Szczecin: Wydawnictwo Naukowe Uniwersytetu Szczecińskiego. 
Witek, M. (2013). Spór między internalizmem i eksternalizmem w teorii aktów mowy. W: P. Stalmaszczyk (red.), Metodologie językoznawstwa: Ewolucja języka, ewolucja teorii językoznawczych (s. 161-177). Łódź: Wydawnictwo Uniwersytetu Łódzkiego.

Witek, M. (2016) Akty mowy. W: J. Odrowąż-Sypniewska (red.), Przewodnik po filozofii języka (s. 367-412). Kraków: Wydawnictwo WAM.

\title{
Possibility Puzzle from Speech Act Theory Perspective
}

\begin{abstract}
The aim of this paper is to analyze the ,possibility puzzle” presented by Shapiro (2011) in the context of the debate between conventionalism and non-conventionalism in speech act theory. Conventionalism claims that for every speech act there is a pattern (convention) which determines its illocutionary force. To perform a felicitous speech act is to fulfil necessary and sufficient conditions for this particular speech act. Non-conventionalism criticizes the view that for every speech act there is a conventional pattern and hidden conditions, which are to be fulfilled. This view maintains the conventional thesis for the so-called strict conventional speech acts (e.g. performatives), but negates using universal quantifier for so-called communicative speech acts whose aim is, in short, to express an intention and force someone to act by virtue of this intention. As in (Shapiro 2011), Phil said: in order for someone to have the power to make, change and apply rules, there has to be a rule that empowers someone to do so. This objection concerned „The First Legislator" only from the conventional perspective on speech acts. If it can be maintained that The First Legislator's speech acts may be non-conventional, then Phil's argument misses the point. Finally, I will emphasize that only lawyers analyze ,the very first speech acts” whereas for philosophers, the problem of e.g. „the very first question” is less absorbing.
\end{abstract}

Keywords: conventionalism; non-conventionalism; possibility puzzle; speech act theory; Shapiro. 